\title{
PHYSICAL PROPERTIES OF DYSTROPHIC RED LATOSOL (OXISOL) UNDER DIFFERENT AGRICULTURAL USES ${ }^{(1)}$
}

\author{
João Tavares Filho( ${ }^{(2)}$, Graziela Moraes de Cesare Barbosa ${ }^{(3)} \&$ \\ Adriana Aparecida Ribon ${ }^{(4)}$
}

\begin{abstract}
Obtaining information about soil properties under different agricultural uses to plan soil management is very important with a view to sustainability in the different agricultural systems. The aim of this study was to evaluate changes in certain indicators of the physical quality of a dystrophic Red Latosol (Oxisol) under different agricultural uses. The study was conducted in an agricultural area located in northern Paraná State. Dystrophic Red Latosol samples were taken from four sites featuring different types of land use typical of the region: pasture of Brachiaria decumbens $(\mathrm{P})$; sugarcane (CN); annual crops under no-tillage (CAPD); and native forest (permanent conservation area) (control (C)). For each land use, 20 completely randomized, disturbed and undisturbed soil samples were collected from the 0 $20 \mathrm{~cm}$ soil layer, to determine soil texture, volume of water-dispersible clay, soil flocculation (FD), particle density, quantity of organic matter (OM), soil bulk density (Ds), soil macroporosity (Ma) and microporosity (Mi), total soil porosity (TSP), mean geometric diameter of soil aggregates (MGD), and penetration resistance (PR). The results showed differences in OM, FD, MGD, Ds, PR, and Ma between the control (soil under forest) and the areas used for agriculture (P, CN and CAPD). The soils of the lowest physical quality were those used for $\mathrm{CN}$ and CAPD, although only the former presented a Ma level very close to that representing unfavorable conditions for plant growth. For the purposes of this study, the physical properties studied were found to perform well as indicators of soil quality.
\end{abstract}

Index terms: land degradation, land use, grazing, sugarcane, no-tillage farming.

\footnotetext{
(1) Received for publication in April 2009 and accepted in February 2010.

(2) Associate Professor at the Department of Agriculture, Londrina State University, CCA/AGR, Post Box 6001, CEP 86051-990 Londrina (PR). E-mail: tavares@uel.br

(3) Research Doctor at the Agricultural Institute of Paraná - IAPAR. Celso Garcia Cid, km 375, CEP 86047-902 Londrina (PR). Email: graziela_barbosa@iapar.br

(4) Assistant Professor at the Department of Geosciences, Londrina State University, CCE/GEO, Post Box 6001, CEP 86051-990 Londrina (PR). email: aaribon@yahoo.com.br
} 


\title{
RESUMO: ATRIBUTOS FÍSICOS DE LATOSSOLO VERMELHODISTRÓFICO PSAMÍTICO SOB DIFERENTES USOS AGRÍCOLAS
}

\begin{abstract}
Obter informações sobre os atributos edáficos do solo sob diferentes usos agrícolas é muito importante para o estabelecimento de manejos adequados, visando à sustentabilidade dos diferentes agrossistemas. O objetivo deste estudo foi avaliar a alteração em alguns atributos indicadores da qualidade física de um Latossolo Vermelho distrófico psamíticos, sob diferentes usos agrícolas. O trabalho foi desenvolvido em uma área de produção agrícola localizada na região Norte do Paraná. A amostragem de solo foi realizada em quatro situações de uso do solo utilizadas em propriedades rurais da região: pastagem de Brachiaria decumbens $(P)$; cana-de-açúcar (SC); culturas anuais em plantio direto (ACNT); e mata nativa (área de preservação permanente), sob LVdp (testemunha (C)). Foram coletadas 20 amostras deformadas e indeformadas por uso do solo, de forma inteiramente casualizada, na camada de 0-20 cm, para determinação da textura do solo, argila dispersa em água, grau de floculação do solo (FD), densidade de partículas, matéria orgânica (OM), densidade do solo (Ds), macroporosidade (Ma) e microporosidade (Mi) do solo, volume total de poros (TSP), diâmetro médio geométrico dos agregados de solo (MGD), além da resistência do solo à penetração $(P R)$. Os resultados permitiram concluir que houve diferença de $M O, F D, D M G, D s$, RP e Ma entre a testemunha (solo sob mata) e os usos agrícolas do solo estudados (P, SCe ACNT); os solos que apresentaram menor qualidade física foram aqueles sob os usos de SC e ACNT, embora somente o uso do solo com SC tenha apresentado valor de Ma muito próximo ao daqueles que representam condições desfavoráveis ao desenvolvimento das plantas. Para as condições de realização deste trabalho, os atributos físicos estudados apresentaram bom desempenho como indicadores da qualidade do solo.
\end{abstract}

Termos de indexação: degradação do solo, uso do solo, pastagem, cana-de-açúcar, plantio direto.

\section{INTRODUCTION}

Caiuá sandstone soils cover approximately $3,000,000$ ha in the north and northwest of the state of Paraná (Brazil). Of this area, which accounts for $15 \%$ of the state, 60 to $65 \%$ is occupied by Latosols. Under natural conditions, the fertility of these soils is low and the physical properties enable infiltration and redistribution of water and oxygen. However, when used for agroforestry activities, the original properties undergo changes that tend towards a new state of equilibrium, which may affect soil and water conservation and crop production.

The different soil management systems aim to create favorable conditions for crop development. However, if the soil conditions are not taken into consideration - whether the soil is moist and friable - and increasingly large and heavy machinery is used, together with highly intensive soil tillage and an inappropriate management of crop residues, the soil structure may be modified, resulting in increased compaction.

Soil compaction can affect soil density, porosity, water infiltration and root growth in crops, thereby reducing crop yield (De Maria et al., 1999; Silva et al., 2000; Tavares Filho et al., 2001; Tormena et al., 2002; Silva et al., 2005).

Structural modifications may differ according to the kind of management system used. It is believed that conventional systems cause the greatest structural changes, since the topsoil is pulverized, making such systems more susceptible to erosion. This results in the formation of physical impediments immediately below the layer of tilled soil (Tavares Filho et al., 2001). Even no-tillage, which was developed to avoiding disturbing the soil and keep it covered with crop residues (De Maria et al., 1999), causes a certain degree of surface compaction, characterized by increased soil density and reduced total porosity (De Maria et al., 1999; Tavares Filho et al., 2001), thereby restricting the crop root growth.

In the case of land used for pasture, trampling by animals, particularly cattle, may alter the physical and hydric properties of the topsoil, increasing density and susceptibility to disaggregation, and reducing total porosity and the water infiltration rate (Gradwell, 1966; Bertol \& Santos, 1995). This may contribute to declines in pasture yields and even advanced stages of land degradation. Such degradation may be caused by a range of interrelated factors, including inappropriate land management, the presence of weeds and, in particular, fertility exhaustion and soil compaction (Soares Filho et al., 1992; Marun \& Mella, 1994). The end result is typically a reduction in stocking density from 2.5 to $3.0 \mathrm{AU} \mathrm{ha}^{-1}$ to around 1.0 AU ha ${ }^{-1}$ (Soares Filho et al., 1992; Marun \& Mella, 1994). 
Accordingly, the soil physical properties, such as density, porosity and mechanical resistance to root penetration can be good indicators of soil quality. They can be used to monitor areas that have suffered some kind of interference and to determine the land use that will minimize further degradation (Arshad et al., 1996). In general, increasing agricultural intensity has been observed to cause modifications in soil structure, with changes in soil aggregate shape, size and stability as well as increased soil density, reduced porosity and increased penetration resistance (Silva \& Mielniczuk, 1997; Alvarenga \& Davide, 1999; Tavares Filho et al., 2001; Silva et al., 2005).

Soil density is affected by the vegetation cover, amount of organic matter and land use and management (Corsini \& Ferraudo, 1999; Silva et al., 2000). Excessive increases in density result in lower physical quality. Various calculations have been made of the critical density limit for the normal growth of plant root systems. According to Arshad et al. (1996), $1.40 \mathrm{~kg} \mathrm{dm}^{-3}$ is generally accepted as the critical limit, although this value increases with declining levels of clay in the soil; for Derpsch et al. (1991), density becomes critical at values of more than $1.25 \mathrm{~kg} \mathrm{dm}^{-3}$; according to Corsini \& Ferraudo (1999), density levels of between 1.27 and $1.57 \mathrm{~kg} \mathrm{dm}^{-3}$ restrict root growth and water infiltration; while Reinert et al. (2001) state that density becomes critical when it reaches around $1.65 \mathrm{~kg} \mathrm{dm}^{-3}$, in the case of sandy soils.

The values of resistance to root penetration may be used to assess the impact of land use and management systems on the compaction process (DiasJúnior \& Pierce, 1996). A level of $2 \mathrm{MPa}$ is widely considered high for the growth of plant root systems. However, the critical resistance value can vary considerably according to the soil texture, structural condition, land management system and crop (Tavares Fiho et al., 2001). Sene et al. (1985) believe that values become critical between 6.0 and $7.0 \mathrm{MPa}$ for sandy soils and at around 2.5 MPa for clayey soils.

Another important factor is soil porosity, particularly the distribution of different pore classes. Macropores are responsible for aeration (aeration porosity) and water infiltration. For most rain-fed crops, an aeration porosity value of less than 10-15\% may limit plant growth, due to lack of oxygen in the roots. Micropores are responsible for retaining and storing water in the soil, for subsequent use by plants. A balance between macropores and micropores in the soil is therefore essential for a healthy plant development.

Considering that soil quality can be monitored based on the soil physical properties, which are sensitive to land management within a determined period of time, the aim of this study was to assess alterations in certain properties indicating physical quality in a dystrophic Red Latosol (Oxisol) soil under different agricultural uses.

\section{MATERIALS AND METHODS}

This study was conducted in an agricultural area in northern Paraná $\left(23^{\circ} 18^{\prime}\right.$ South, and $51^{\circ} 30$ ' West). The area in the basin of the river Bandeirantes do Norte, is flat to gently undulating, with an average altitude of $550 \mathrm{~m}$. It has a Cfa climate according to the Köppen classification system, with hot summers and an average annual temperature of $21^{\circ} \mathrm{C}$, and annual precipitation of 1,400 to $1,500 \mathrm{~mm}$; June, July and August compriare the least rainy quarter $(325 \mathrm{~mm})$. The soil of the area studied is mainly derived from Caiuá Formation sandstone and classified as a dystrophic Red Latosol.

Soil samples of dystrophic Red Latosol were taken from four sites, featuring different land uses typical of the region, as follows: (1) Permanent and continuous extensive cattle pasture of Brachiaria decumbens (P), renewed in 1999 through plowing, harrowing and broadcast sowing of grasses. The area has no terrace agriculture; (2) Sugarcane (CN), planted since 1998 in an area previously used for extensive pasture. The area was plowed, then harrowed and furrowed for sugarcane planting. The area is cultivated in terraces; (3) Annual crops (soybean and corn in the second growing season) under no-tillage (CAPD), in an area used until 2000 for extensive pasture. The pasture was desiccated with glyphosate, plowed and harrowed before planting the 2000 crop (corn), and thereafter the area was used for annual no-tillage crops. The area has agricultural terraces; and 4) Native forest (permanent conservation area) (control (C)).

Since the study involved an evaluation of different field situations, it was necessary to collect a greater number of samples for each agricultural use to cover the natural variability of the soil. To further reduce the chances of experimental error, the agricultural areas for soil sampling were chosen according to their proximity, similar topographical positions and the same soil class, with a homogeneous soil profile (Table 1).

In December 2008, for each of the agricultural uses described above, 20 completely random disturbed soil samples were collected from the 0-20 cm soil layer, to determine soil texture (Tavares Filho \& Magalhães, 2008), volume of water-dispersible clay, soil flocculation, particle density and quantity of organic matter, in line with Embrapa (1997). Twenty completely random samples of undisturbed soil were also collected from the $0-20 \mathrm{~cm}$ soil layer from each location, using a $50.26 \mathrm{~cm}^{3}$ cylindrical sampler, to determine soil bulk density, macroporosity and microporosity by the tension table method (Embrapa, 1997), and total soil porosity by summing the values for macro- and microporosity. Close to the cylindrical sampler collection points, additional soil samples were taken to determine the mean geometric diameter of soil aggregates, following the method proposed by Castro Filho et al. (1998). 
Table 1. Mean values for particle density $(\mathrm{Pd})$ and dystrophic Red Latosol texture of the three composite samples taken from the 0-20 cm soil layer, based on 20 simple samples for each land use profile

\begin{tabular}{|c|c|c|c|c|c|}
\hline \multirow{2}{*}{ Land use } & \multirow{2}{*}{ Dp } & \multicolumn{3}{|c|}{ Soil texture } & \multirow{2}{*}{ Water - dispersed clay } \\
\hline & & Sandy & Silty & Clayey & \\
\hline & $\mathrm{kg} \mathrm{dm}{ }^{-3}$ & \multicolumn{3}{|c|}{$\mathrm{g} \mathrm{kg}^{-1}$} & $\mathrm{~g} \mathrm{~kg}^{-1}$ \\
\hline $\mathrm{P}$ & $2.64 \mathrm{~A}$ & $900.1 \mathrm{~A}$ & $9.2 \mathrm{~A}$ & $90.7 \mathrm{~A}$ & $11.80 \mathrm{~A}$ \\
\hline $\mathrm{CN}$ & $2.66 \mathrm{~A}$ & $890.9 \mathrm{~A}$ & $9.3 \mathrm{~A}$ & $99.8 \mathrm{~A}$ & $14.10 \mathrm{~A}$ \\
\hline CAPD & $2.65 \mathrm{~A}$ & $892.2 \mathrm{~A}$ & $8.9 \mathrm{~A}$ & $98.9 \mathrm{~A}$ & $10.40 \mathrm{~B}$ \\
\hline $\mathrm{C}$ & $2.65 \mathrm{~A}^{(1)}$ & $893.1 \mathrm{~A}$ & $9.1 \mathrm{~A}$ & $97.8 \mathrm{~A}$ & $4.20 \mathrm{~B}$ \\
\hline CV (\%) & 1.11 & 0.57 & 2.33 & 5.30 & 47.33 \\
\hline
\end{tabular}

(1) Mean values followed by the same letters, within the same column, did not differ from each other at a significance level of $5 \%$ by the Tukey test. P: extensive pasture; CN: sugarcane; CAPD: annual crops under no-tillage; C: control.

Mean soil penetration resistance, to a depth of $40 \mathrm{~cm}$, was established in 20 samples for each land use (Tavares Filho \& Ribon, 2008) with an impact penetrometer (model IAA/PLANALSUCAR STOLF), following the method described by Stolf et al. (1983). In the penetrometer tests, which were carried out at the same time the cylindrical samples were taken, the soil density and gravimetric water content were also determined. The calculations were made in line with Stolf (1991), and the results presented in $\mathrm{MPa}$, after transforming the values obtained into $\mathrm{kgf}^{-2}$ based on the use of the constant 0.0981 .

The results were presented in mean values, and a $95 \%$ confidence interval was calculated for a comparison of the values obtained for each agricultural use.

\section{RESULTS AND DISCUSSION}

\section{Organic matter (OM)}

The content of soil OM (Figure 1) in the control (C - soil under native forest) was higher than that found in the three different agricultural uses, which did not differ from each other. The differences between the mean absolute values of $\mathrm{OM}$ for $(\mathrm{C})$ and the soils used for different agricultural uses were not negligible. The differences were $1.66 \mathrm{dag} \mathrm{kg}^{-1}$ between (C) and (P); $2.28 \mathrm{dag} \mathrm{kg}^{-1}$ between $(\mathrm{C})$ and $(\mathrm{CN})$; and $1.33 \mathrm{dag} \mathrm{kg}^{-1}$ between (C) and (CAPD).

These results show that the mean absolute content of OM was most diminished in the soil under sugarcane $(\mathrm{CN})$, with a mean absolute content of $\mathrm{OM}$ around $69 \%$ lower than in the soil under native forest (C). The corresponding value was approximately $50 \%$ for the soil under pasture (P) and around $40 \%$ for the soil under annual crops in a no-tillage system (CAPD).

The low amount of OM in the soil under sugarcane (CN) is probably due to the effects of the burning of crop residues before the crop is harvested. These results are in line with those found by Giovannini \&
Luchesi (1997) and Heringer et al. (2002), who report that the long-term consequence of soils under pasture with annual controlled fires are lower levels of soil OM. No effect was however observed at depths below $10 \mathrm{~cm}$, since fires only raise the soil temperature in the topsoil (Neves \& Miranda, 1996).

Accordingly, if $\mathrm{OM}$ is considered a factor of key relevance in low-activity soils such as the Red Latosol soils under study, activities that reduce OM contents should be avoided. OM plays an important role in supplying nutrients, accounting for at least $56 \%$ of the Cation Exchange Capacity (CEC) in such soils (Raij, 1987), besides improving the soil physical properties (aggregation, structure and water dynamics).

In addition, it is known that a reduction in $\mathrm{OM}$ lcontents tends to increase soil solution $\mathrm{Al}$ activity, resulting in a hostile environment for plants. This is due to the fact that when organo-mineral complexes are formed in the presence of OM, the latter controls soil solution $\mathrm{Al}$ activity as well as exchangeable $\mathrm{Al}$, so that the $\mathrm{Al}$-organic matter complexes lose their toxic effects for plants (Siqueira, 1986). Consequently, regular crop residue burning tends to affect the soil

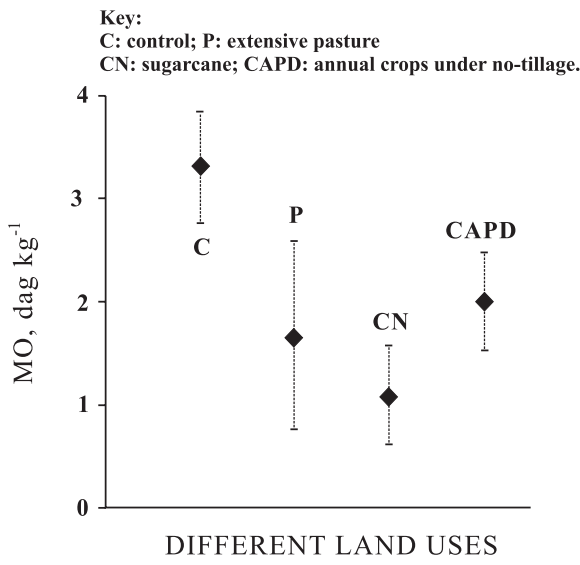

Figure 1. Mean values and confidence interval (95 \%) for organic matter (OM), calculated for the 0 $20 \mathrm{~cm}$ soil layer in areas of different land uses. 
negatively, in contrast to statements that it can improve the soil and increase nutrient supply (Schacht et al., 1996).

\section{Flocculation degree (FD) of the soil}

In terms of the soil flocculation degree (FD), the FD observed in the control (C) differs at a significance level of $5 \%$ from the other land uses, which do not differ from each other (Figure 2).

The results for flocculation may be explained by the following two hypotheses: 1) They are a reflection of OM contents, which influences the soil structure greatly; 2) The results are of mechanical nature, since soil preparation, particularly in the case of land used to grow sugarcane $(\mathrm{CN})$, may increase clay dispersion (Eltz et al., 1989; Levy et al., 1993), thereby reducing the soil flocculation degree.

In the present study, flocculation was lowest were OM levels were found to be lowest, without differences between the results. According to Chaney \& Swift (1984) and Prado \& Centurion (2001), OM is a soil stabilizing agent, raising the flocculation degree; it may therefore be considered an indicator of aggregate stability and erodibility. In terms of the second hypothesis - that soil preparation affects FD - the results show that where land management is most intense (CN, CAPD), FD is the lowest.

\section{Mean geometric diameter (MGD)}

No mean result for MGD exceeded $2 \mathrm{~mm}$, even in the case of the soil under native forest (C) (Figure 3), indicating a tendency of low aggregate stability in these sandy soils. In addition, the MGD result for the control (C) differs at a significance level of $5 \%$ from the other land uses, which do not differ from each other. Alvarenga \& Davide (1999) and Wohlenberg et al. (2004) also observed reductions in aggregate stability in tillage systems due to the land management techniques employed.

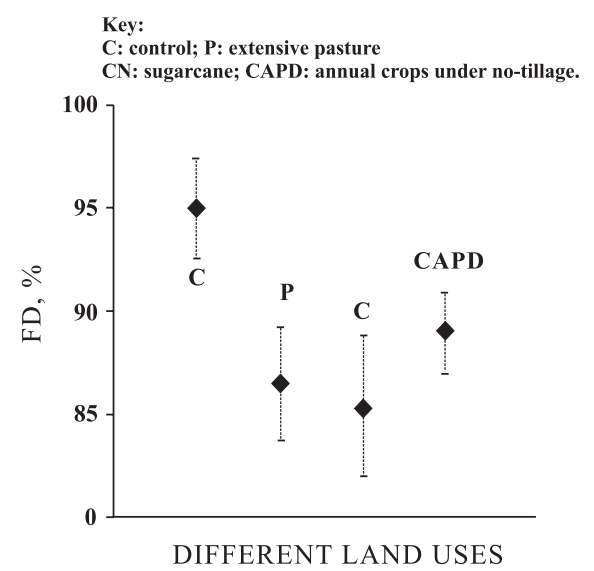

Figure 2. Mean values and confidence interval (95\%) for soil flocculation degree (FD), calculated for the 0-20 cm soil layer in areas of different land uses.

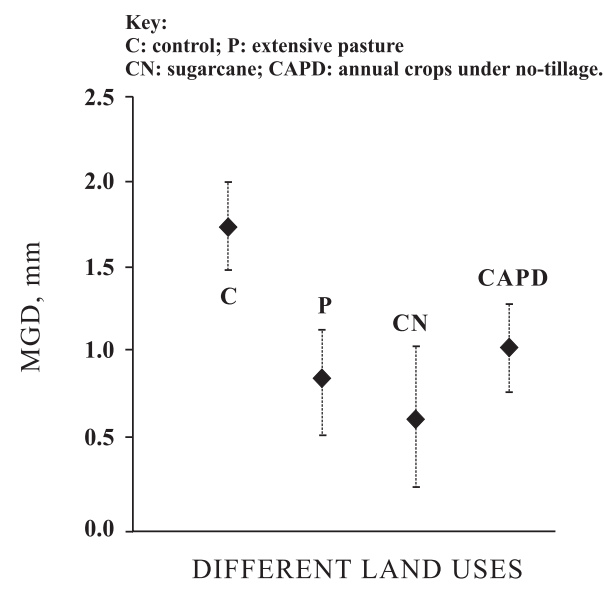

Figure 3. Mean values and confidence interval (95\%) for mean geometric diameter of soil aggregates (MGD), calculated for the $0-20 \mathrm{~cm}$ soil layer in areas of different land uses.

Interestingly, a similar pattern occurred for the content of organic matter (Figure 1), indicating a correlation between the content of OM in the soil and soil aggregation (Castro Filho et al., 1998; Beutler et al., 2001; Cruz et al., 2003; Neves et al., 2007). These results are in line with Wohlenberg et al. (2004), who observed greater structural stability in sandy soil under grassland and lower soil aggregation under bare soil. According to the authors, this is due to intensive land preparation, which reduces the content of OM and increases the quantity of smaller sized aggregates.

In the case of soil under pasture $(\mathrm{P})$ and sugarcane (CN), the differences in OM and soil aggregate (MGD) quantities compared with the soil under native forest (C) could indicate a reduction in the $\mathrm{C}$ stock due to fallen leaves and plant matter. This seems to occur to a lesser extent in the case of annual crops under no-tillage (CAPD). These results highlight the importance of maintaining OM in sandy soils. According to Silva \& Mielniczuk (1997), the magnitude of structural alterations depends on the soil texture and mineralogy. Consequently, knowing that sandy soils have a low CEC makes OM as an indispensable component of structural maintenance.

\section{Soil density (Ds) and penetration resistance (PR)}

It was observed that the Ds values (Figure 4) in the soil under native forest (control (C)) were lower than those in the three different agricultural uses, which did not differ from each other. The differences between the mean absolute Ds values for $(C)$ and the soils under different agricultural uses are not negligible: between (C) and (P), Ds increased $0.28 \mathrm{Mg} \mathrm{m}^{-3}$; between (C) and (CN), Ds increased $0.59 \mathrm{Mg} \mathrm{m}^{-3}$; and between (C) and (CAPD), Ds increased $0.50 \mathrm{Mg} \mathrm{m}^{-3}$. These results show that the mean absolute Ds value was most affected in the soil under sugarcane $(\mathrm{CN})$. 

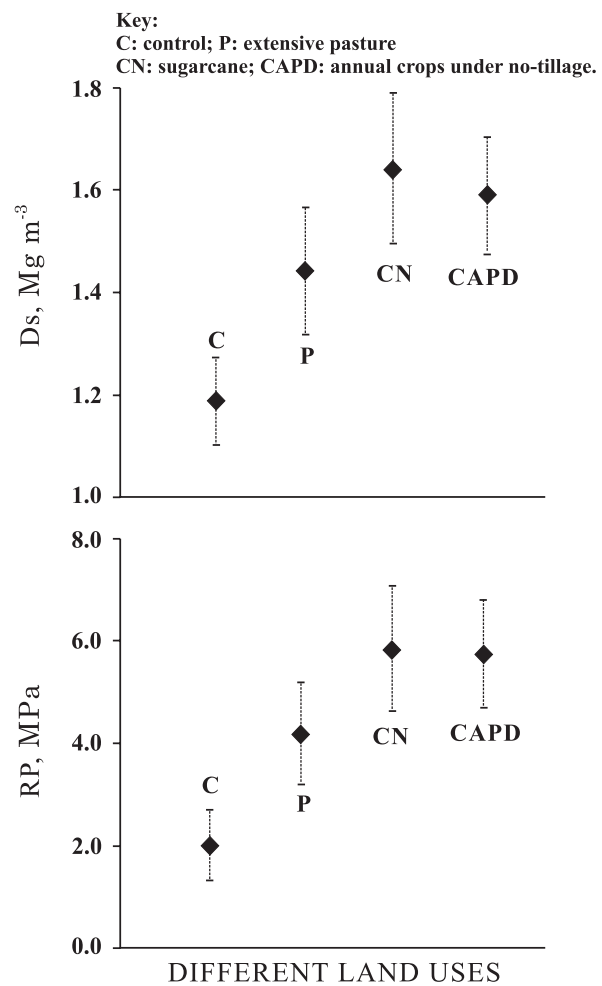

LAND USE

Gravimetric water content $\left(\mathrm{kg} \mathrm{kg}^{-1}\right)$ at the

$\begin{array}{ll}\mathrm{C} & 0.22 \\ \mathrm{P} & 0.19 \\ \mathrm{CN} & 0.19 \\ \mathrm{CAPD} & 0.21\end{array}$

Figure 4. Mean values and confidence interval (95\%) for soil density (Ds) - calculated for the 0-20 cm soil layer - and soil penetration resistance (PR) - calculated for the 0-40 cm soil layer - in areas of different land use.

Increased Ds results in lower soil porosity (particularly macroporosity). Accordingly, if one considers the soil volume to a depth of $0.20 \mathrm{~m}$, these Ds increases correspond to a reduction in porosity of $180 \mathrm{~m}^{3} \mathrm{ha}^{-1}$ in the soil under pasture (P), $440 \mathrm{~m}^{3} \mathrm{ha}^{-1}$ in the soil under sugarcane $(\mathrm{CN})$ and $360 \mathrm{~m}^{3} \mathrm{ha}^{-1}$ in the soil under annual no-tillage crops (CAPD), when compared with the soil under native forest (C), with a total porosity of $1,240 \mathrm{~m}^{3} \mathrm{ha}^{-1}$.

Of the three agricultural land uses, the Ds in the soil under pasture $(\mathrm{P})$ increased least in comparison with the control (C), despite animal trampling. This is probably due to a stronger soil structure caused by microorganisms that decompose organic matter in notillage systems, as well as the action of the root system throughout the cultivation (Muller et al., 2001; Silva et al., 2005).

The higher Ds in the soil under sugarcane $(\mathrm{CN})$ indicates the extent to which intense use of agricultural machinery can be harmful in terms of soil disaggregation, causing successive soil participle compression, which leads to structural degradation and increased density (Dias Júnior \& Pierce, 1996; Bertol et al., 2000).

In the case of the land used for annual crops under no-tillage (CAPD), the higher Ds could be a consequence both of soil particle accommodation after the land use had been implemented and of the use of heavy machinery (tractors, seeders and harvesters) in planting and harvesting operations (Silva et al., 2000; Costa et al., 2003; Silva et al., 2005).

Ds is affected by vegetation cover, OM content and land use and management (Corsini \& Ferraudo, 1999; Silva et al., 2000). Various calculations have been made of the critical density limit for the normal growth of plant roots. According to Arshad et al. (1996), $1.40 \mathrm{~kg} \mathrm{dm}^{-3}$ is generally accepted as the critical limit, although this value increases with declining clay levels in the soil; for Derpsch et al. (1991), density becomes critical at values of more than $1.25 \mathrm{~kg} \mathrm{dm}^{-3}$; according to Corsini \& Ferraudo (1999), density levels of 1.27$1.57 \mathrm{~kg} \mathrm{dm}^{-3}$ restrict root growth and water infiltration; while Reinert et al. (2001) state that density becomes critical when it reaches around $1.65 \mathrm{~kg} \mathrm{dm}^{-3}$, in the case of sandy soils.

Accordingly, since the soil under all land uses studied is sandy, with a clay content less than $100 \mathrm{~g} \mathrm{~kg}^{-1}$ in all cases (Table 1), the highest Ds values observed - those for CN (Ds $\left.=1.61 \mathrm{~kg} \mathrm{dm}^{-3}\right)$ and CAPD $\left(1.52 \mathrm{~kg} \mathrm{dm}^{-3}\right)$ - do not indicate a high compaction that could restrict growth and development of the plant root systems or cause problems in terms of water infiltration, soil aeration or restriction of biological activity.

For penetration resistance (Figure 4), the results obtained followed the same pattern as observed for Ds, i.e., the value under native forest (control (C)) differed from the three land uses, which did not differ from each other, and the differences were not negligible: $\mathrm{PR}$ increased 2.34 $\mathrm{MPa}$ between $(\mathrm{C})$ and $(\mathrm{P})$; $4.30 \mathrm{MPa}$ between $(\mathrm{C})$ and $(\mathrm{CN})$; and $4.00 \mathrm{MPa}$ between (C) and (CAPD). These results show that the mean absolute PR value, as in the case of Ds, was affected by land management involving agricultural machinery (CN and CAPD).

A value of $2 \mathrm{MPa}$ for $\mathrm{PR}$ is widely considered high for the growth of plant roots. However, the critical resistance value can vary considerably according to the soil texture, structural conditions, land management system and crop (Tavares Fiho et al., 2001). Sene et al. (1985) consider values critical between 6.0 and $7.0 \mathrm{MPa}$ for sandy soils and around 2.5 MPa for clayey soils. Similar values were obtained for soil under sugarcane $(\mathrm{CN})$ and annual crops under no-tillage (CAPD), 5.52 and 5.42 MPa respectively. This indicates that restrictions to crop root development may occur if measures to reverse the situation are not taken, such as the use of subsoilers and subsequent rotation with crops of different root systems. 
Soil porosity: total soil porosity (TSP), macroporosity (Ma) and microporosity (Mi)

The results for soil porosity in the $0-20 \mathrm{~cm}$ soil layer under the different land uses (Figure 5) showed that for the TSP and Mi parameters, there was no significant difference between the control (C) and the soils used for agriculture. In the case of $\mathrm{Ma}$, the control (C) and pasture (P) results did not differ, but the (C) result did differ from the values for sugarcane $(\mathrm{CN})$ and annual crops under no-tillage (CAPD), while the latter two did not differ from the result for $\mathrm{P}$.

In terms of TSP, Bertol et al. (2004) stated that the higher the Ds (Figure 4), the lower the TSP, and this was indeed observed for all land uses studied. The higher Ds than in the soil under native forest $(\mathrm{C})$ was correlated with reduced TSP. This is probably due to reduction in Ma. However, in the case of soil under pasture $(\mathrm{P})$, the Ma results may indicate a lack of sensitivity to cattle trampling in the soil layer analyzed $(0-20 \mathrm{~cm})$, and may also suggest a strong influence of the Brachiaria root system on soil structure. The Ma value observed in the soil under pasture $(\mathrm{P})$ is very important, because it shows there is effective oxygen diffusion and rainwater drainage in the soil profile, which corresponds to a lower risk of erosion.

On the other hand, the Ma results for soil under sugarcane $(\mathrm{CN})$ and annual crops under no-tillage (CAPD), with lowest absolute macroporosity values, differ from the findings of Tormena et al. (2002) and Neves et al. (2007), who reported that increases in Ma are probably due to soil tillage using agricultural machinery.

Since porosity is a direct consequence of the organization of primary particles in the soil, this parameter may be considered to be one of the best quantitative indicators for revealing and evaluating structural degradation phenomena. Ideal total soil porosity (TSP) for a healthy plant development is

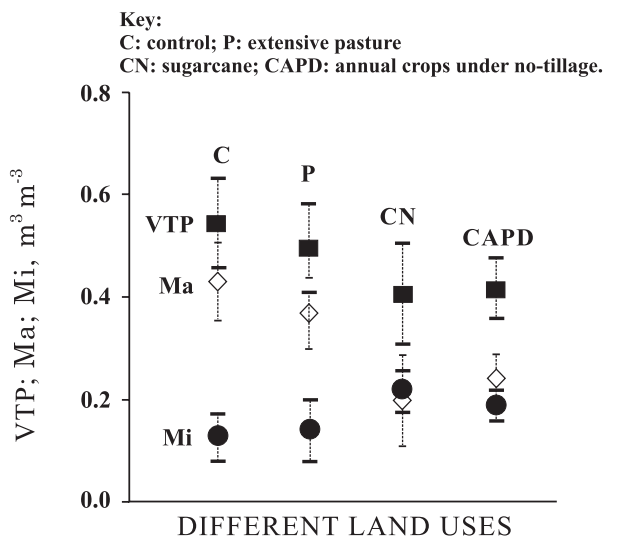

Figure 5. Mean values and confidence interval (95\%) for total soil porosity (TSP), macroporosity (Ma) and microporosity (Mi), calculated for the 0 $20 \mathrm{~cm}$ soil layer in areas of different land use. around $0.50 \mathrm{~m}^{3} \mathrm{~m}^{-3}$, with a distribution of at least $1 / 3$ macropores and the rest micropores. In addition, to allow gas exchanges and root growth of most rain-fed crops, Ma should be greater than $0.10 \mathrm{~m}^{3} \mathrm{~m}^{-3}$.

The TSP results obtained for soil porosity indicate that soils under sugarcane $(\mathrm{CN})$ and annual crops under no-tillage (CAPD) are below the minimum indicated as ideal, and the $1 / 3 \mathrm{Ma}$ value is slightly higher than the limit value (10\%), with Ma practically equal to $\mathrm{Mi}$, in the soil under sugarcane $(\mathrm{CN})$. This indicates that, in terms of soil porosity, the conditions for plant development are only unfavorable under $\mathrm{CN}$. These results show the extent to which sugarcane management, from planting until harvest, is demanding in terms of heavy machinery use, thereby causing soil compaction (Stone \& Silveira, 2001; Silva et al., 2005).

\section{CONCLUSIONS}

1. Differences in OM, FD, MGD, Ds, PR, and Ma were detected between the control soil (forest) and the soils used for agriculture: pasture (P), sugarcane (CN) and annual crops under no-tillage (CAPD).

1. The soil indicators used show that the cultivation of sugarcane $(\mathrm{CN})$ and of annual crops under no-tillage (CAPD) are both soil-degrading compared to the other uses studied.

2. Only in the soil under sugarcane $(\mathrm{CN})$ the $\mathrm{Ma}$ value came very close to the critical value representing unfavorable conditions for plant growth and development.

3. For the purposes of this study, the physical properties studied were found to perform well as indicators of soil quality.

\section{LITERATURE CITED}

ALVARENGA, M.I.N. \& DAVIDE, A.C. Características físicas e químicas de um Latossolo Vermelho-Escuro e a sustentabilidade de agroecossistemas. R. Bras. Ci. Solo, 23:933-942, 1999 .

ARSHAD, M.A.; LOWERY, B. \& GROSSMAN, R. Physical test for monitoring soil quality. In: DORAN, J.W. \& JONES,A. J., eds. Methods for assessing soil quality. Madison, Soil Science Society of America, 1996. (Special Publication Number, 49)

BERTOL, I. \& SANTOS, J.C.P. Uso do solo e propriedades físico-hídricas no Planalto Catarinense. Pesq. Agropec. Bras., 30:263-267, 1995.

BERTOL, I.; ALBUQUERQUE, J.A.; LEITE, D.; AMARAL, A.J. \& ZOLDAN JÚNIOR, W.A. Propriedades físicas do solo sob preparo convencional e semeadura direta em rotação e sucessão de culturas, comparadas à do campo nativo. $R$. Bras. Ci. Solo, 28:155-163, 2004. 
BERTOL, I.; SCHICK, J.; MASSARIOL, J.M.; REIS, E.F. \& DILY, L. Propriedades físicas de um Cambissolo Húmico álico afetadas pelo manejo do solo. Ci. Rural, 30:91-95, 2000 .

BEUTLER, A.N.; SILVA, M.L.N.; CURI, N.; FERREIRA, M.M.; PEREIRA FILHO, I.A. \& CRUZ, J.C. Resistência à penetração e permeabilidade de Latossolo Vermelho distrófico típico sob sistemas de manejo na região dos cerrados. R. Bras. Ci. Solo, 25:167-177, 2001.

CASTRO FILHO, C.; MUZILli, O. \& PODANOSCH, I. Estabilidade dos agregados e sua relação com o teor de carbono orgânico num Latossolo Roxo distrófico, em função de sistemas de plantio, rotações de cultura e métodos de preparo das amostras. R. Bras. Ci. Solo, 22:527538, 1998.

CHANEY, K. \& SWIFT, R.S. The influence of organic matter on aggregate stability in some British soils. J. Soil Sci., 35:223-230, 1984.

CORSINI, P.C. \& FERRAUDO, A.S. Efeitos de sistemas de cultivo na densidade e macroporosidade do solo e no desenvolvimento radicular do milho em Latossolo Roxo. Pesq. Agropec. Bras., 34:289-298, 1999.

COSTA, F.S.; ALBUQUERQUE, J.A.; BAYER, C.; FONTOURA, S.M.V. \& WOBETO, C. Propriedades físicas de um Latossolo Bruno afetadas pelos sistemas plantio direto e preparo convencional. R. Bras. Ci. Solo, 27:527-535, 2003.

CRUZ, A.C.R.; PAULETO, E.A.; FLORES, C.A. \& SILVA, J.B. Atributos físicos e carbono orgânico de um Argissolo Vermelho sob sistemas de manejo. R. Bras. Ci. Solo, 27:1105-1112, 2003.

DE MARIA, I.C.; CASTRO, O.M. \& DIAS, H.S. Atributos físicos do solo e crescimento radicular de soja em Latossolo Roxo sob diferentes métodos de preparo do solo. R. Bras. Ci. Solo, 23:703-709, 1999.

DERPSCH, R.; ROTH, C.H.; SIDIRAS, N. \& KÖPKE, U. Controle da erosão no Paraná, Brasil: Sistemas de cobertura do solo, plantio direto e preparo conservacionista do solo. Eschborn, GTZ/IAPAR, 1991. 268 p.

DIAS JÚNIOR, M.S. \& PIERCE, F.J. O processo de compactação do solo e sua modelagem. R. Bras. Ci. Solo, 20:175-182, 1996.

ELTZ, F.L.F.; PEIXOTO, R.T.G. \& JASTER, F. Efeitos de sistemas de preparo do solo nas propriedades físicas e químicas de um Latossolo Bruno álico. R. Bras. Ci. Solo, 13:259-267, 1989.

EMPRESA BRASILEIRA DE PESQUISA AGROPECUÁRIA . EMBRAPA. Serviço Nacional de Levantamento e Conservação de Solo. Manual de métodos de análise de solo. Rio de Janeiro, Ministério da Agricultura, 1997. 212p.

GIOVANNINI, G. \& LUCCHESI, S. Modifications induced in soil physical-chemical parameters by experimental fires at different intensities. Soil Sci., 162:479-486, 1997.

GRADWELL, M.W. Soil moisture deficiencies in puddled pastures. New Zealand J. Agric. Res., 9:127-136, 1966.
HERINGER, I.; JACQUES, A.V.A.; BISSANI, C.A. \& TEDESCO, M. Características de um Latossolo Vermelho sob pastagem natural sujeita à ação prolongada do fogo $\mathrm{e}$ de práticas alternativas de manejo. Ci. Rural, 32:309-314, 2002.

LEVY, G.J.; EISENBERG, H. \& SHAINBERG, I. Clay dispersion as related to soil properties and water permeability. Soil Sci., 155:15-22, 1993.

MARUN, F. \& MELLA, S.C. Recuperação de pastagens no Noroeste do Paraná através da sucessão de culturas por um ano. Londrina, IAPAR, 1994, 15p. (Informe de Pesquisa, 111)

MÜLLER, M.M.L.; GUIMARÃES, M.F.; DESJARDINS, T. \& MARTINS, P.F.S. Degradação das pastagens na Região Amazônica: Propriedades físicas do solo e crescimento das raízes. Pesq. Agropec. Bras., 36:1409-1418, 2001.

NEVES, B.M.C. \& MIRANDA, H.S. Temperatura do solo em um campo sujo de cerrado durante uma queimada prescrita. In: PEREIRA, R.C. \& NASSER, L.C.B. SIMPÓSIO SOBRE O CERRADO, 8., Brasília, 1996. Biodiversidade e produção sustentável de alimentos e fibras no cerrado. Anais... Planaltina, Embrapa-CPAC, 1996. p.396-399.

NEVES, C.M.N.; SILVA, M.L.N.; CURI, N.; CARDOSO, E.L.; MACEDO, R.L.G.; FERREIRA, M.M. \& SOUZA, F.S. Atributos indicadores da qualidade do solo em sistema agrossilvopastoril no noroeste do Estado de Minas Gerais. Sci. For., 74:45-53, 2007.

PRADO, R.M. \& CENTURION, J.F. Alterações na cor e no grau de floculação de um Latossolo Vermelho-Escuro sob cultivo contínuo de cana-de-açúcar. Pesq. Agropec. Bras., 36:197-203, 2001.

RAIJ, B.van. Avaliação da fertilidade do solo. Piracicaba, POTAFOS, 1987. 142p.

REINERT, D.J.; REICHERT, J.M. \& SILVA, V.R. Propriedades físicas dos solos em sistemas de plantio direto irrigado. In: CARLESSO, R.; PETRY, M.T.; ROSA, G.M. \& CERETTA, C.A. Irrigação por aspersão no Rio Grande do Sul. Santa Maria, Palloti, 2001. 156p.

SCHACHT, W.H.; STUBBENDIECK, T.; BRAGG, T.B.; SMART, A.J. \& DORAN, J.W. Soil quality response of reestablished grasslands to mowing and burning. J. Range Manag., 49:458-463, 1996.

SENE, M.; VEPRASKAS, M.J.; NADERMAN, G.C. \& DENTON, H.P. Relationships of soil texture and structure to corn yield response to subsoiling. Soil Sci. Soc. Am. J., 49:422-427, 1985.

SILVA, I.F. \& MIELNICZUK, J. Ação do sistema radicular de plantas na formação e estabilização de agregados do solo. R. Bras. Ci. Solo, 21:113-117, 1997.

SILVA, R.R.; SILVA, M.L.N. \& FERREIRA, M.M. Atributos físicos indicadores da qualidade do solo sob sistemas de manejo na bacia do Alto do Rio Grande (MG). Ci. Agrotec., 29:719-730, 2005.

SILVA, V.R.; REINERT, D.J. \& REICHERT, J.M. Densidade do solo, atributos químicos e sistema radicular do milho afetados pelo pastejo e manejo do solo. R. Bras. Ci. Solo, 24:191-199, 2000. 
SIQUEIRA, C. Calagem para plantas forrageiras. In: SIMPÓSIO SOBRE CALAGEM E ADUBAÇÃO DE PASTAGENS, 1., Nova Odessa, 1985. Anais. Piracicaba, Associação Brasileira para Pesquisa da Potassa e do Fósforo, 1986. p.77-91.

SOARES FILHO, C.V.; MONTEIRO, F.A. \& CORSI, M. Recuperação de pastagens degradadas de Brachiaria decumbens. 1. Efeito de diferentes tratamentos de fertilização e manejo. Past. Trop., 14:2-6, 1992.

STOLF, R. Teoria e teste experimental de fórmulas de transformação dos dados de penetrômetro de impacto emresistência do solo. R. Bras. Ci. Solo, 15:229-235, 1991.

STOLF, R.; FERNANDES, J. \& FURLANI NETO, V.L. Recomendação para uso do penetrômetro de impacto modelo IAA/PLANALSUCAR/STOLF;. STAB - Açúc. Alcool Subprod., 3:18-23, 1983.

STONE, L.F. \& SILVEIRA, P.M. Efeitos do sistema de preparo e da rotação de culturas na porosidade e densidade do solo. R. Bras. Ci. Solo, 25:395-401, 2001.
TAVARES FILHO, J. \& RIBON, A.A. Resistência do solo à penetração em resposta ao número de amostras e tipo de amostragem. R. Bras. Ci. Solo, 32:1429-1435, 2008.

TAVARES FILHO, J.; BARBOSA, G.M.C.; GUIMARÃES, M.F. \& FONSECA, I.C.B. Resistência do solo à penetração e desenvolvimento do sistema radicular do milho (Zea mays) sob diferentes sistemas de manejo em um Latossolo Roxo. R. Bras. Ci. Solo, 25:725-730, 2001.

TAVARES-FILHO, J. \& MAGALHÃES, F.S. Dispersão de amostras de Latossolo Vermelho eutroférrico influenciadas por pré-tratamento para oxidação da matéria orgânica e pelo tipo de agitação mecânica. R. Bras. Ci. Solo, 32:1429-1435, 2008.

TORMENA, C.A.; BARBOSA, M.C.; COSTA, A.C.S. \& GONÇALVES, C.A. Densidade, porosidade e resistência à penetração em Latossolo cultivado sob diferentes sistemas de preparo do solo. Sci. Agric., 59:795-801, 2002.

WOHLENBERG, E.V.; REICHERT, J.M.; REINERT, D.J. \& BLUME, E. Dinâmica da agregação de um solo francoarenoso em cinco sistemas de culturas em rotação e em sucessão. R. Bras. Ci. Solo, 28:891-900, 2004. 